\title{
CZARNE KSIĘGI REWOLUCJI FRANCUSKIEJ
}

FrançoIs Souchal, Wandalizm rewolucji, tłum. i komentarze Paweł Migasiewicz, Fundacja Augusta hr. Cieszkowskiego, Warszawa 2016, ss. 373+1

Ukazujące się współcześnie w Polsce publikacje naukowe dotyczące mrocznych stron rewolucji francuskiej z 1789 r. zapełniają wprawdzie lukę w historiografii, jednak w szerszym odbiorze często wywołują niedowierzanie. Przez całe dziesięciolecia kształtował się pogląd, że było to wydarzenie ze wszech miar pozytywne, w związku z czym powszechnie nazywano je Wielką Rewolucją Francuską, a o mrocznych stronach wspominano niechętnie, jedynie przy okazji, uwypuklając pozytywne aspekty. Oczywiście, badacze epoki mieli świadomość nieustającej dyskusji i ścierania się różnych racji w historiografii francuskiej, czy nawet zachodnioeuropejskiej, oraz istnienia tam znaczącej literatury przedmiotu odnoszącej się do tej problematyki krytycznie, niemniej do szerokiego odbiorcy w Polsce informacje te nie docierały. Wynikało to $\mathrm{z}$ jednej strony $\mathrm{z}$ braku wolności badań naukowych w okresie komunizmu (o rewolucji można było pisać dobrze albo nie pisać w ogóle), z drugiej zaś - z powodu bariery językowej. Kto znał język francuski, przy odrobinie wysiłku mógł zapoznać się z publikacjami Michela Vovelle'a czy Jacques'a Godechota'. Wydaje się wszakże znaczący przypadek dobrej i wyważonej książki Pierre'a Gaxotte'a Rewolucja francuska z 1970 r., która przekładu na język polski doczekała się dopiero w roku $2001^{2}$. Na thumaczenie mogły natomiast liczyć dzieła takich autorów, jak admirator jakobinów Albert Soboul ${ }^{3}$; odwoływano się też do prac François A. Aularda czy Alberta Mathieza, bo prezentowały one pozytywny obraz tych krwawych wydarzeń. Nie należy jednak zapominać, że i w czasach PRL-u pojawiały się publikacje wskazujące te wypadki z okresu jakobińskiej dyktatury, które były całkowicie nie do obrony ${ }^{4}$.

1 Np. M. Vovelle, Religion et révolution la déchristianisation de l'an II, Paris 1976; J. Godechot, Les révolutions (1770-1799), Paris 1970.

2 P. Gaxotte, La Révolution Française, Paris 1970. Wydanie polskie: tenże, Rewolucja francuska, thum. J. Furuhielm, A. Zawilski, E. Kruczkowska, Gdańsk 2001.

3 Zob. A. Soboul, W. Markov, Wielka rewolucja Francuzów 1789, thum. E. Marciniec, WrocławKraków-Warszawa 1984.

4 Zob. S. Salmonowicz, Wandea. Anatomia ludowej kontrrewolucji, „Kwartalnik Historyczny”, 74(1967), z. 4, s. 945-962. 
Niemniej musimy pamiętać, że charakterystyczny dla leninowskich bolszewików kult rewolucji francuskiej oraz marksistowskie przekonanie o jej nieuchronności i korzystnym wpływie na rozwój ludzkości odegrały potem zasadniczą rolę w tworzeniu historiografii tej epoki w krajach środkowej i wschodniej Europy.

Pretekstem do szerokiej dyskusji historycznej na temat rewolucji francuskiej stała się dwusetna rocznica jej wybuchu, obchodzona hucznie w 1989 r. Wydarzenia te, celebrowane właściwie w całej Europie, dały asumpt do publikacji także polskim historykom zauważającym mroczną stronę rewolucji, przede wszystkim wydarzeń związanych z okresem władzy jakobinów ${ }^{5}$. Mimo to wydaje się, że w polskiej historiografii ciągle jeszcze obecne jest przekonanie o wielkości i wspaniałości rewolucji francuskiej, będące pokłosiem historiografii tworzonej w czasach słusznie minionych, w których wydarzenie to stanowiło ikonę determinizmu w historii.

Dyskusja nad dziejami rewolucji francuskiej jest ważna i nie powinniśmy od niej odchodzić, także dlatego, że wydarzenie to odegrało znaczącą rolę w dziejach kontynentu, zapoczątkowało szereg idei i ideologii do dziś wpływających na kształt polityczny Europy i świata. Współcześnie w Polsce pojawia się coraz więcej publikacji krytycznych wobec rewolucji francuskiej, pokazujących wyniki badań nad dokonanymi wówczas zbrodniami. Co charakterystyczne, są to głównie tłumaczenia autorów francuskich. Wydaje się, że niezwykle ważne miejsce zajmuje wśród nich wydana w 2015 r. Czarna księga rewolucji francuskiej. Jest to tłumaczenie obszernej, w wersji polskiej liczącej 1064 strony pracy zbiorowej pod redakcją naukową Renauda Escande' $a^{6}$. Zawiera artykuły 47 francuskich historyków umieszczone w trzech częściach: 1. Fakty (25 tekstów), 2. Duch (20) oraz 3. Antologia, obejmująca wybrane teksty źródłowe dotyczące omawianych zagadnień. Dzieło to, pomyślane jako pewnego rodzaju odniesienie do Czarnej księgi komunizmu ${ }^{7}$, ukazuje całą mroczną i brutalną stronę rewolucji w odniesieniu do monarchicznej tradycji Francji, Kościoła i ludzi jawiących się rewolucjonistom strażnikami starego porządku. Jako wrogów rewolucji i w imię postępu, który mieli rzekomo powstrzymywać, należało ich zlikwidować. Autorzy wskazują, że szaleństwo budowy „nowego, wspaniałego świata” uderzało bezpośrednio w tra-

5 Zob. tenże, Rewolucja francuska: blaski i cienie dziedzictwa, „Przegląd Historyczny”, 81(1990), z. 1-2, s. 75-85. Nieco późniejszy jest artykuł Moniki Senkowskiej-Gluck dotyczący francuskiej historiografii tego okresu: M. SENKOwSKA-GLucK, Rewolucja francuska 1789 roku przed sądem historii, w: Między polityka a kulturą, red. C. Kuklo, Warszawa 1999, s. 393-409.

6 Czarna księga rewolucji francuskiej, red. R. Escande, tłum. K. Kubaszczyk, B. Biały, J. Gruszka, M. Jurek, Kraków 2015 (tytuł oryginału: Le Livre noir de la Révolution français).

7 S. Courtors i in., Czarna księga komunizmu. Zbrodnie, terror, prześladowania, przeł. K. Wakar, wstęp K. Kersten, Warszawa 1999. 
dycję i pamięć narodu, albowiem jedynie wykorzenienie go z tradycji pozwalało mieć nadzieję na szybkie uwieńczenie rewolucyjnych wysiłków sukcesem. Nawiasem mówiąc, po zapoznaniu się z tą mroczną syntezą rewolucyjnego obłędu nie będzie dla czytelnika niczym nadzwyczajnym zachwyt bolszewików nad rewolucją francuską, szczególnie w wydaniu jakobińskim. Lektura tej publikacji pozostawia jednak pewien niedosyt. Powracać musi pytanie o racje - czemu stosowany wobec rodaków bezprzykładny terror miał służyć. Czy zabijanie w imię idei czy nowego pomysłu ustrojowego wydaje się normalne? Jak zrozumieć rewolucyjne szaleństwo?

Szczególnym domknięciem obrazu okrucieństwa rewolucji francuskiej - poniekąd absurdalnego i barbarzyńskiego - jest opatrzona znamiennym tytułem Wandalizm rewolucji ${ }^{8}$ publikacja François Souchala poświęcona niszczeniu historyczno-kulturalnego dziedzictwa Francji. Ten francuski archiwista, paleograf i historyk sztuki jest wybitnym znawcą rzeźby francuskiej z czasów Ludwika XIV i Ludwika XV, wieloletnim profesorem Université de Paris - X, Archivés Nationales i Musées Nationoux oraz byłym długoletnim redaktorem „Gazette des Beaux-Arts”. Napisana w konwencji eseju książka powstała na skutek szoku badawczego, którego autor doznał w trakcie swoich wieloletnich badań naukowych, kiedy uświadomił sobie skalę zniszczeń dokonanych w niespotykanym wręcz tempie. Zubożenie dziedzictwa artystycznego Francji w okresie rewolucji do dziś utrudnia, a czasem wręcz uniemożliwia badanie sztuki, szczególnie rzeźby okresu przedrewolucyjnego, której autor poświęca wiele uwagi (należy jednak podkreślić, że obiektem swoich zainteresowań uczynił całość francuskiego dziedzictwa).

Oparty na solidnej podstawie źródłowej esej jest opowieścią o jednym z aspektów rewolucji: pokazuje mechanizmy niszczenia wybitnych i niepowtarzalnych dzieł sztuki. Momentami czytelnik odnosi wrażenie, że narracja przeradza się w ponury katalog przytłaczający skalą i szaleństwem niszczenia wszystkiego. Rozległość rewolucyjnego wandalizmu rodzi pytania zarówno o przyczyny (co autor wyjaśnia), jak i o sposób takiego kierowania masami niszczycieli, aby zadanie to wykonywali bez oporu, a nawet z satysfakcją i zapałem. Bez odpowiedzi pozostaje jednak to pytanie: „Czy Francuzi są szczególnie uzdolnieni do praktykowania wandalizmu; czy nie czerpią z tej praktyki swego rodzaju upajającej radości, jak gdyby zawzięcie chcieli zmusić przedmioty, by naginały się do meandrów ich idei?"9. Brzmi ono szczególnie ponuro w kontekście innych wymienionych rewolucji: hiszpańskiej wojny domowej, rewolucji angielskiej i kilkakrotnie przywołanej rewolucji bolszewickiej - równie lub bardziej krwawych, jednak niepochłaniających

8 F. Souchal, Wandalizm rewolucji, tłum. i komentarze P. Migasiewicz, Warszawa 2016.

9 Tamże, s. 340. 
tak ogromnej ilości dziedzictwa narodowego swoich krajów. Dlaczego więc Francuzi wykazali tak ogromną pasję niszczenia?

Zdaniem Souchala zapoczątkowała ją nienawiść wobec religii. Rewolucja, nim wymknęła się spod kontroli, była starannie wyreżyserowanym przedsięwzięciem, mającym na celu wykorzenienie z Francji chrześcijaństwa. Autor zwraca uwagę, że do pierwszych aktów wandalizmu dochodziło na długo przed obaleniem monarchii, a brak szacunku Francuzów dla dziedzictwa artystycznego da się zauważyć w ich temperamencie już wcześniej. Wandalizm rewolucji jest jednak czymś więcej - to przejaw głębokiej nietolerancji połączonej z głupotą i fanatyzmem.

Na marginesie należy dodać, że Souchal nie jest pierwszym we francuskiej historiografii badaczem podejmującym temat bezprzykładnego niszczenia dziedzictwa sztuki w czasie rewolucji. W 1959 r. ukazała się publikacja Louisa Réau pod znamiennym tytułem: Histoire du vandalisme. Le monuments détruits de l'art français ${ }^{10}$. Autor ten jednak, skądinąd naukowy mentor Souchala, inaczej rozłożył akcenty i jako antyklerykał w mniejszym stopniu odniósł się do zniszczeń substancji artystycznej pozostającej w domenie Kościoła. Souchal uważa natomiast, że rewolucja miała przede wszystkim charakter antychrześcijański i antykościelny, więc pierwotny wandalizm skierowany był przeciwko Kościołowi, a potem przeciwko temu, co łączyło się z Kościołem i religią, tzn. monarchii, arystokracji itd. Co charakterystyczne, w Polsce nie poświęcano tej tematyce szczególnej uwagi. W 1960 r. Andrzej Wyrobisz opublikował recenzję pracy Réau ${ }^{11}$, zarzucając mu tendencyjność, ale jednocześnie podkreślał, że w czasie rewolucji we Francji miały miejsce działania pozytywne, np. wydawanie dekretów przeciwko niszczeniu zabytków. To prawda i żaden z francuskich autorów tego nie ukrywał. Problem w tym, że prawa te nie miały żadnego znaczenia, ponieważ pozostawały jedynie na papierze, podczas gdy te same organy władzy rewolucyjnej wydawały jednocześnie dekrety nakazujące wymazanie z przestrzeni kraju wszelkich pozostałości ancien regime’u. Inni polscy historycy zajmujący się problematyką rewolucji francuskiej, jak Stefan Meller czy Jan Baszkiewicz, nie poświęcali tej problematyce większej uwagi, zajmując się raczej analizą nowych idei czy przemian społecznych. Niekiedy wspominano jedynie o zniszczeniu królewskiej nekropolii w opactwie St. Denis pod Paryżem. Można zatem powiedzieć, że kwestia wandalizmu rewolucyjnego jest w naszym kraju zagadnieniem mało znanym, i to nie tylko szerszemu społeczeństwu, ale nawet wielu badaczom epoki.

${ }^{10}$ L. RÉAU, Histoire du vandalisme. Le monuments détruits de l'art français, t. 1: Du haut Moyen Age au XIXe siècle; t. 2: XIXe et XXe siècle, Paris 1959.

${ }^{11}$ A. Wyrobisz, Louis Réau, „Histoire du vandalisme. Les monuments détruits de l'art français”, Librairie Hachette, ,, Bibliothèque des Guides Bleus”, Paris 1959, t. I- „Du haut Moyen Age au XIXe siècle”, s. 420; t. II - ,XIX ${ }^{e}$ - et XX $X^{e}$ siècles”, s. 342, „Przegląd Historyczny”, 51(1960), z. 4, s. 756760. 
Souchal w swoich rozważaniach wychodzi od pojęcia wandalizm, które ukute zostało dopiero w okresie rewolucji - przez duchownego, biskupa konstytucyjnego Henriego Grégoire'a. Był on autorem trzech raportów o niszczeniu zabytków, a także pamiętników, w których przypisał sobie autorstwo tego terminu. Wydaje się jednak, że nie jest to prawdą, ponieważ już w XVIII w. na określenie bezmyślnego niszczenia używano sformułowań: „barbarzyństwo” czy „,naśladowanie Gotów i Wandalów". Grégoire dawał wyraz swojemu sprzeciwowi wobec niszczycielskich działań rewolucjonistów, ale robił to dość wybiórczo - nie wszystko jego zdaniem powinno być bowiem chronione. Tak czy inaczej jego protesty nie odniosły żadnego skutku. Souchal rozprawia się w swojej książce z dotychczasową francuską historiografią, tuszującą działania rewolucjonistów, m.in. poprzez podnoszenie tezy, że i we wcześniejszych epokach dość bezmyślnie niszczono pewne dzieła. Tak - odpowiada - ale skala zjawiska była wówczas niewielka i usuwano część zabytków, by zrobić miejsce dla innych dzieł, odpowiadających nowym gustom estetycznym. Nie było to niszczenie dla niszczenia czy - co gorsza - dla wymazania z pamięci świata istnienia francuskiej monarchii.

Antyklerykalizm Réau spowodował, że umieścił on wandalizm skierowany przeciwko Kościołowi na trzecim miejscu, za działaniami wymierzonymi w monarchię i szlachtę. Zdaniem Souchala należy go jednak wskazać jako pierwotny - to Kościół rewolucja chciała zniszczyć przede wszystkim, gdyż w jego gestii znajdowały się oświata, opieka medyczna, opieka społeczna oraz liczne dobra. Autor zauważył ciekawe zjawisko, które przeczy tezie o całkowitej spontaniczności wybuchu zamieszek w Paryżu w lipcu 1789 r. Nim doszło do zdobycia Bastylii, 12 lipca podpalono, a następnie rozgrabiono w stolicy klasztor misjonarzy!

Jako szczególny punkt zwrotny Souchal przyjmuje wprowadzenie w $1790 \mathrm{r}$. cywilnej konstytucji kleru, na mocy której wszystkie kościoły we Francji, które straciły księży (najczęściej dlatego, że odmówili złożenia przysięgi na wierność konstytucji), podlegały nacjonalizacji. Uznane za zbędne, wystawiane były na sprzedaż, co najczęściej wiązało się z rozgrabieniem i sprzedaniem wyposażenia (m.in. zagranicznym kolekcjonerom), przetopieniem miedzi, ołowiu i kruszców czy wreszcie rozbiórką niepotrzebnych budynków lub zmianą ich przeznaczenia, co też łączyło się z dokonywaniem w świątyniach licznych bluźnierstw. Wszystkie te czynności wykonywały liczne grupy sankiulotów, którzy - jak zauważa autor musieli się skądś rekrutować. Opisywane działania od samego początku motywowane były ideologią, najczęściej doprowadzaną do absurdu, jak choćby obsesja równości. Jej ofiarami padły tysiące kościelnych wież i iglic gotyckich katedr, które wybijały się ponad inne budynki. Inną obsesją rewolucjonistów było usuwanie wszelkich ozdób noszących symbole monarchiczne czy szlacheckie, jak herby, 
wizerunki i portrety - i to jeszcze przed zniesieniem monarchii. Iglica St. Chapelle w Paryżu została zniszczona dlatego, że wieńczyła ją korona.

Souchal nie wymienia zbyt wielu nazwisk niszczycieli dziedzictwa sztuki francuskiej, gdyż były to raczej akty zbiorowe, jednak poza Grégoire'em w jego książce pojawia się jeszcze kilka osób. Przede wszystkim jest to szczególnie „zasłużony" François Daujon, mierny rzeźbiarz, dobry jakobin, człowiek odpowiadający za zniszczenie iglicy St. Chapelle. To właśnie on najął się do zniszczenia wszelkich monarchicznych i szlacheckich symboli w przestrzeni publicznej. Skuwał więc wraz z pomocnikami herby, emblematy, korony i burbońskie lilie, najczęściej niszcząc bezpowrotnie arcydzieła rzeźby gotyckiej, renesansowej i późniejszych epok, rujnując portale katedr i wizerunki świętych. Do rzadkości nie należała wcale, zwłaszcza w okresie jakobińskim, dekapitacja figur na tympanonach, portalach, wieżach i wewnątrz świątyń lub też przerabianie świętych na antycznych herosów, m.in. przez dorabianie im czapek frygijskich. Inną wspominaną przez Souchala postacią, na poły złowrogą, na poły ocierającą się o farsę, był przedsiębiorca budowlany, niejaki Palloy, który podjął się rozbiórki Bastylii i jeszcze dodatkowo zarobił, wykonując z poszczególnych kamieni rzeźby, najczęściej samej twierdzy, a następnie sprzedając je po całej Francji jako okolicznościowe gadżety.

Autor odniósł się też do osoby Aleksandra Lenoira, kierującego umieszczonym w paryskim klasztorze augustianów mniejszych składem rzeźb pochodzących z rozbieranych kościołów i pałaców, które uznano za wartościowe. Nie da się ukryć, że uratowano w ten sposób wiele dzieł sztuki, m.in. sporo odlewów z brązu, które Lenoir oblepiał gipsem i tak chronił przed przetopieniem. $Z$ drugiej jednak strony selekcjonował dzieła według własnych zapatrywań, samemu też przyczyniając się do destrukcji, zwłaszcza grup rzeźbiarskich przez ich podział i dowolne zestawianie, a przede wszystkim trwałe usunięcie z naturalnego miejsca przeznaczenia. Niejako w obronie Lenoira należałoby powiedzieć, że w końcu XVIII w. nie istniały jeszcze współczesne zasady konserwacji i ochrony zabytków, więc działał on tak, jak uważał to za najlepsze. Niemniej wpisywał się w ciąg zbrodni przeciwko dziedzictwu artystycznemu swojej ojczyzny.

Dochodzimy tu do myśli przewodniej całej książki o wandalizmie rewolucji francuskiej. Korzystając z formuły eseju, Souchal pozwala sobie na ujawnienie bardzo emocjonalnego stosunku do zagadnienia. Robi to na dwóch poziomach - jako historyk i historyk sztuki, który nie może przeboleć gigantycznego uszczerbku w zabytkowej substancji, oraz jako Francuz, przeżywający do głębi to, co jego rodacy z tą substancją byli w stanie zrobić. Nie unika więc dosadnych ocen, np. „głupiec La Fayette”, „zbrodnia”, „masakry”, „rzeź pomników”, „ślepy obłęd”, a kolejnym rozdziałom nadaje tytuły: martyrologium kościołów paryskich, katedr, klasztorów, 
pałaców itd. W pewnych partiach książka jest nieco nużąca i przytłaczająca - staje się katalogiem wyliczanych z wielką starannością strat. Najbardziej smutna jest jednak konstatacja, że jest to tylko cząstka informacji, dotycząca tych dzieł, o których wiemy z przekazów źródłowych, że istniały i zostały zniszczone. Na francuskiej prowincji nikt nie inwentaryzował zabytków, nie można ich więc wymienić, bo nie ma świadectwa ich istnienia. Autor wylicza więc kolejno paryskie kościoły, klasztory, katedry w całym kraju, wskazując zniszczenia, jakich doznały: rabunki, zmiana przeznaczenia, sprzedaż, rozbiórki, kradzieże wyposażenia, konfiskata dzwonów i odlewów z brązu oraz cennych metali. Te ostatnie trafiały do przetopienia: brąz na armaty, a cenne metale do mennicy. Wiele wyrobów jubilerskich sprzedano zagranicznym kolekcjonerom; zostały być może dzięki temu ocalone, ale też bezpowrotnie stracone dla francuskiej kultury. Dramatyczne były losy kościelnych bibliotek i archiwów - wiele z przechowywanych tam dzieł, w szczególności pergaminowych, zostało całkowicie zniszczonych, gdyż przerabiano je na woreczki do kul dla armii. Ze ścian zawilgoconych krypt kościelnych pozyskiwano saletrę do produkcji prochu, przyczyniając się jednocześnie do ich dalszej degradacji, a wiele gotyckich opactw i kościołów stało się podręcznymi kamieniołomami dla okolicznych mieszkańców. Wydaje się, że najtragiczniejszy pod tym względem był okres władzy jakobinów, kiedy to „bandy sankiulockich szaleńców masakrowały katedry" (Souchal zaznacza też jednak, że termidorianie wcale nie byli lepsi). Kościoły traktowano wówczas jako przejaw fanatyzmu, zabobonu, który należało zwalczać za wszelką cenę. Twierdząc, że Jezus był dobrym sankiulotą i żył w ubóstwie, jakobini wydali szereg dekretów, na mocy których należało pozbyć się z przestrzeni publicznej wszelkich oznak zabobonu, co równało się niszczeniu kościołów, kaplic oraz wszelkich budowli i przedmiotów związanych z minioną epoką. Komitet Ocalenia Publicznego nakazał np. likwidację herbów. Skutkiem tej decyzji było również zniszczenie licznych znaków własności oraz oszpecenie budowli i rzeźb, ale też dewastacja wielu obrazów i ogromnej liczby zbiorów bibliotecznych, które zwyczajowo opatrywane były herbami właścicieli. Choć Souchal opiera się na raportach Grégoire'a, to generalnie ocenia go negatywnie, twierdząc, że duchowny nie chciał się narażać, więc nie uczynił nic, aby powstrzymać obłęd niszczenia. Zauważa, że jego raporty są bardzo chaotyczne i niespójne oraz że dość wybiórczo traktował dziedzictwo historyczne i artystyczne swojego kraju. Jako bibliofil z dużym pietyzmem odnosił się do księgozbiorów, których niszczenie, rozkradanie, wyprzedaż, zwłaszcza do Anglii, poruszało go najbardziej. Grzmiał wtedy i starał się protestować, niemniej nie na wiele mogło się to wówczas zdać.

Souchal zwrócił uwagę na jeszcze jedno zjawisko: paradoksalnie rewolucja zrażała do siebie ludzi, którzy początkowo wcale nie byli jej wrogami. Omawiając 
wandalizm skierowany przeciwko szlachcie, zauważył, że spora część tego stanu nie była nastawiona do zmian bardzo negatywnie. Historyk mógłby dodać, że uciążliwość systemu społeczno-prawnego w ówczesnej Francji dostrzegała nie tylko burżuazja, ale też wielu przedstawicieli stanów uprzywilejowanych. Rewolucja jednak już od początku zwracała się przeciwko wszystkiemu, co wiązało się z ancien regime'em, a więc także przeciwko szlachcie, poczynając od tzw. wielkiej trwogi z przełomu lipca i sierpnia 1789 r., czyli masowego plądrowania zamków i dworów oraz niszczenia dworskich archiwów, a przy okazji siedzib szlacheckich. Apogeum tych wydarzeń miała być dewastacja całego szlacheckiego dziedzictwa Francji po upadku monarchii. Wobec zorganizowanych band sankiulockich wszelkie próby ratowania zabytków i dzieł sztuki nie na wiele się zdały. Szczególną odsłoną niszczenia pamięci po francuskiej szlachcie była dewastacja nagrobków, zwłaszcza uważanych za przejawy zabobonu rzeźb. „Wandalizm przeciw nagrobkom” pochłonął taką masę wybitnych nieraz dzieł sztuki sepulkralnej - od wczesnego średniowiecza, przez barok, po klasycyzm - że nie ma nawet możliwości stworzenia katalogu strat. Rujnowano je zarówno wraz ze świątyniami, jak też osobno, jako relikty epoki, która miała zostać wymazana z dziejów Francji. W ten sposób w gruzach legły pomniki nagrobne mało znanych postaci, jak i bohaterów Francji. Po 10 sierpnia 1792 r. niszczycielski impet skierowany został w stronę monarchii. Rozpoczęła się wówczas dewastacja wszelkich wizerunków królów oraz - co może się wydawać całkowicie niedorzeczne - rujnowanie pałaców królewskich. Nie przejęto ich na własność narodu, ale wystawiono na grabieże. Wszystko zaczęło się w Tuilleries, a 25 sierpnia 1793 r. rozpoczęto trwającą bez kilku dni rok wyprzedaż Wersalu. Część dzieł, w tym portrety monarchów i członków rodzin królewskich, po prostu spalono. W celu odzyskania srebrnych i złotych nici wypalano też tapiserie, a biżuterię i inne cenne przedmioty sprzedawano lub rozkradano. Najbardziej mrocznym dziełem rewolucji było jednak zdewastowanie i sprofanowanie grobów królewskich w St. Denis. Te wydarzenia znamy dość dobrze z opisu Grégoire'a, a Souchal przedstawił je momentami tak naturalistycznie, że czytelnik ma wrażenie uczestniczenia w swoistym dance macabre. Decyzja o zlikwidowaniu królewskiej nekropolii zapadła w Konwencie dla uczczenia rocznicy obalenia tyranii, którą zaczęto obchodzić już w sierpniu 1793 r. Przez kilka kolejnych miesięcy otwierano groby francuskich monarchów i wyrzucano szczątki do wspólnego dołu (nie ominęło to świątobliwej córki Ludwika XV, karmelitanki Madame Louise), nagrobki rozbijano, a ołowiane trumny czy wszelkie mosiężne i brązowe elementy przetapiano. Sponiewieranie zwłok wydaje się być szczytem barbarzyństwa. Souchal stawia nam te obrazy przed oczyma, zastanawiając się, jak wśród osiemnastowiecznych oświeconych (!) Francuzów mogły się narodzić tak zwyrodniałe postawy. 
Odpowiedź znajdziemy w następnym rozdziale: Wandalizm przeciw archiwom. Autor zauważył, że już 29 lipca 1789 r., a więc na samym początku rewolucji, wydane zostało rozporządzenie o utworzeniu Archiwów Narodowych, mające służyć scaleniu wszystkich archiwów: państwowych, urzędowych, miejskich i prywatnych. Ostatecznie doprowadziło to do zniszczenia wszystkiego, co zostało uznane za zbyteczne (szczególnie w czasach rządów jakobinów). Od 1792 r. płonęły w miastach ogromne ogniska, do których bez mrugnięcia okiem wrzucano całe tomy akt miejskich i prywatnych dokumentów, które traktowano jako wybrakowane i niepotrzebne, choć tak naprawdę nikt nie badał ich zawartości i znaczenia dla dziejów Francji. „Francja paliła swoją historię”12 - zauważa Souchal, i właśnie o to chodziło. W dalszych rozdziałach wspomina jeszcze o niszczeniu miast, które ośmieliły się zbuntować przeciwko rewolucji, jak Lyon i Toulon, czy były tylko papieskie, jak Awinion. Wskazuje też na systematyczne niszczenie substancji materialnej zbuntowanej Wandei ${ }^{13}$ i wreszcie zauważa, że wandalizm wraz z armią rewolucyjną przeniesiony został poza granice Francji. Rabunki dzieł sztuki w Belgii, Holandii i Włoszech dokonywane były w przekonaniu, że należą się one Francuzom, gdyż budują oni nowy, wspaniały świat. A jednak to podsumowanie rozprawienia się z archiwami stanowi istotę i kwintesencję dzieła rewolucjonistów. Bezprzykładna dewastacja dziedzictwa artystycznego i historycznego, dokumentacji dziejów i wreszcie będących miejscami pamięci grobów mówi o jednym: ideologiczne zacietrzewienie rewolucjonistów miało doprowadzić do wymazania francuskiej spuścizny z pamięci następnych pokoleń. Francuzi mieli nie wiedzieć nic o historii swojego kraju i narodu. Zarówno ona, jak i wszystkie dokonania przodków miały zostać pochłonięte przez ogień, a na zgliszczach miał powstać zupełnie nowy świat, skrojony na miarę wyobraźni ojców rewolucji - barbarzyńców XVIII w. To właśnie stanowi szczególnie mocne podsumowanie istoty rewolucji w mrocznej książce François Souchala. O ile bowiem wojnę domową - z całym jej okrucieństwem i nawet terrorem - można thumaczyć argumentami o walce politycznej obrońców starego porządku z buntującą się częścią narodu, która domagała się zmian społecznych, politycznych itp., to nie da się inaczej wytłumaczyć próby zrównania z ziemią ponad tysiącletniej przeszłości Francji. Wojna wypowiedziana własnej tożsamości, przybierająca różnego rodzaju potworne formy palenia własnej historii, jest czymś niewytłumaczalnym. Można wprawdzie powiedzieć, że o tym wiedzieliśmy, niemniej jednak skumulowanie w jednej książce wiedzy

\footnotetext{
${ }^{12}$ F. Souchal, Wandalizm..., s. 315.

${ }^{13}$ W kwestii wandejskiego ludobójstwa odsyła do książki: R. SECHER, La génocide franco-français. La Vendée - Vengé, 1986. Wydanie polskie: tenże, Ludobójstwo francusko-francuskie. Wandeadepartament zemsty, Warszawa 2003.
} 
o niszczeniu własnego dziedzictwa i pamięci nie pozwala przejść obok niej obojętnie. Souchal pozostawia czytelnika z obrazami bestialstwa i niewyobrażalnego wandalizmu dokonanego nie rękami wrogów i okupantów, ale rodaków, a także z koniecznością samodzielnego poszukania odpowiedzi na pytanie, czym jest istota rewolucji i jakie otchłanie obłędu otwiera ideologiczne szaleństwo rewolucjonistów. Jeżeli do obrazu zbrodni na ludziach i całym narodzie dodamy niszczenie tradycji i pamięci zamkniętych w dziedzictwie kulturowym, to zobaczymy pełnię totalności rewolucji, która wiedzie cały naród w stronę chaosu. Nowy wspaniały świat rewolucjonistów jest w istocie chaosem, w którym nie ma żadnych odniesień. Oderwanie od korzeni, a nawet głęboka nienawiść wobec nich, zacierająca w rzeczywistości wszelkie ślady tradycji, nie jest w stanie niczego zbudować, bo nie daje żadnego punktu oparcia. O ile więc wspomniane wcześniej publikacje w większym lub mniejszym stopniu ukazują grozę i szaleństwo rewolucji, to książka Souchala dotyka już jej metafizycznego zła - zła, które jest zaprzeczeniem całego sensu istnienia.

\section{BIBLIOGRAFIA}

Courtors S. i in., Czarna księga komunizmu. Zbrodnie, terror, prześladowania, przeł. K. Wakar, wstęp K. Kersten, Warszawa 1999.

Czarna księga rewolucji francuskiej, red. R. Escande, thum. K. Kubaszczyk, B. Biały, J. Gruszka, M. Jurek, Kraków 2015.

Gaxotte P., La Révolution Française, Paris 1970.

Gaxotte P., Rewolucja francuska, tłum. J. Furuhielm, A. Zawilski, E. Kruczkowska, Gdańsk 2001. Godechot J., Les révolutions (1770-1799), Paris 1970.

RÉAu L., Histoire du vandalisme. Le monuments détruits de l'art français, t. 1: Du haut Moyen Age au XIXe siècle; t. 2: XIXe et XXe siècle, Paris 1959.

Salmonowicz S., Rewolucja francuska: blaski i cienie dziedzictwa, „Przegląd Historyczny”, 81(1990), z. 1-2, s. 75-85.

Salmonowicz S., Wandea. Anatomia ludowej kontrrewolucji, „Kwartalnik Historyczny”, 74(1967), z. 4, s. 945-962.

SECHER R., La génocide franco-français. La Vendée - Vengé, 1986.

SECHER R., Ludobójstwo francusko-francuskie. Wandea-departament zemsty, Warszawa 2003.

SenkowsKa-Gluck M., Rewolucja francuska 1789 roku przed sq̨dem historii, w: Między polityka a kultura, red. C. Kuklo, Warszawa 1999, s. 393-409.

Soboul A., Markov W., Wielka rewolucja Francuzów 1789, thum. E. Marciniec, Wrocław-KrakówWarszawa 1984.

Souchal F., Wandalizm rewolucji, tłum. i komentarze P. Migasiewicz, Warszawa 2016.

Vovelle M., Religion et révolution la déchristianisation de l'an II, Paris 1976; 
Wyrobisz A., Louis Réau, „Histoire du vandalisme. Les monuments détruits de l'art français”, Librairie Hachette, ,, Bibliothèque des Guides Bleus”, Paris 1959, t. I- „, Du haut Moyen Age au XIXe siècle”, s. 420; t. II - „XIX ${ }^{e}$ - et XX $X^{e}$ siècles”, ss. 342, „Przegląd Historyczny”, 51(1960), z. 4, s. $756-760$.

Ewa M. Ziółek Instytut Historii Katolicki Uniwersytet Lubelski Jana Pawła II ewamargo@kul.lublin.pl 